Article

\title{
Understanding the University-Sustainability Link through Media: A Spanish Perspective
}

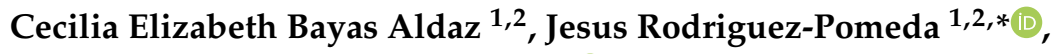 \\ Leyla Angélica Sandoval Hamón 1,2 1 and Fernando Casani ${ }^{1,2}$ \\ 1 Department of Business Organization, Universidad Autónoma de Madrid, 28049 Madrid, Spain; \\ cecilia.bayas@uam.es (C.E.B.A.); angelica.sandoval@uam.es (L.A.S.H.); fernando.casani@uam.es (F.C.) \\ 2 Research Institute for Higher Education and Science (INAECU), 28903 Madrid; Spain \\ * Correspondence: jesus.pomeda@uam.es; Tel.: +34-91-497-4323
}

Received: 3 April 2020; Accepted: 10 June 2020; Published: 12 June 2020

\begin{abstract}
This article provides a procedure to universities for understanding the social perception of their activities in the sustainability field, through the analysis of news published in the printed media. It identifies the Spanish news sources that have covered this issue the most and the topics that appear in that news coverage. Using a probabilistic topic model called Latent Dirichlet Allocation, the study includes the nine dominant topics within a corpus with more than seventeen thousand published news items (totaling approximately five and a quarter million words) from a database of almost thirteen hundred national press sources between 2014 and 2017. The study identifies the news sources that published the most news on the issue. It is also found that the amount of news on sustainability and universities declined during the covered period. The nine identified topics point towards the relevance of higher education institutions' activities as drivers of sustainability. The social perception encapsulated within the topics signals how the public is interested in these activities. Therefore, we find some interesting relationships between sustainable development, higher education institutions' missions and behaviors, governmental policies, university funding and governance, social and economic innovation, and green campuses in terms of the overall goal of sustainability.
\end{abstract}

Keywords: sustainability; higher education institution; university; social perception; topic modelling; media; governmental policies; greener campus

\section{Introduction}

In 1987, the Brundtland Commission Report, "Our Common Future", defined sustainable development as "the development that meets the needs of the present without compromising the ability of future generations to meet their own needs" [1] (p. 17). The report emphasized the importance of cooperation among different stakeholders for societies to progress towards a more sustainable future for humankind [1]. In particular, concerns about the impact of human activities on the natural, social, and economic environment have led to worldwide calls for organizational accountability, transparency, and stakeholder engagement [2]. Since then, the general concept of sustainability, which integrates environmental, social, and economic perspectives and applies them to sustainable development, has regularly begun to be considered at different levels of all kinds of organizations. Thus, "sustainability is an issue of increasing importance in today's world" [3] (p. 216).

Growing social concern regarding sustainability has boosted media coverage of the efforts realized by different actors. Additionally, sustainability concerns are now a tacit or explicit norm for governments and several sectors of the economy, including higher education [4]. The interaction among global, international (e.g., the United Nations), governmental, and educational institutions has resulted in a broad variety of recommendations for sustainability in higher education institutions 
(HEIs). At the same time, in the academic world, the key role that higher education should play in the overall process-aligning its main mission and operations for sustainable education-has been emphasized by different authors [5-11]. Accordingly, the proliferation of conferences, declarations, and agreements on integrating sustainability in higher education institutions has steadily increased. For instance, in 1994, 1000 universities reaffirmed the Copernicus University Charter for Sustainable Development of Agenda 21 (with a 2.0 update in 2011) in a lengthy agreement to build sustainable universities [12]. For more examples of declarations, measures, and assessments, see [13-20].

Universities around the world have made efforts to incorporate sustainability into their activities through different initiatives. Nevertheless, integrating sustainability in all their processes requires that HEIs implement the management approach known as "stakeholder engagement", which is defined as "practices that the organization undertakes to involve stakeholders" [21] (p. 421). The stakeholder approach began in the mid-1980s, when R. Edward Freeman defined the term as "any group or individual who can affect or is affected by the achievement of the organization's objectives" [22] (p. 46). This theory acknowledges the importance of managers' time and attention to these internal or external groups of individuals, who could contribute to the value the organization creates. If HEIs want to overcome their social education challenge and contribute significantly to the social quest for more sustainable societies, then it is essential for them to act on the challenges, problems, lifestyles, and actions of social groups external to universities.

In this sense, Lozano [23] presented a basic model for sustainable development in universities. This model considered mainly internal stakeholders' attitudes and behaviors. The model has three main parts: (1) university governance (leadership, engagement, institutional framework and policies); (2) community outreach (campus operations, research, curricula, and competencies); and (3) sustainability assessment and reporting. However, sustainability in HEIs is not only what is done but also how it is done. The "how" includes "classroom dynamics, decision-making processes, organizational structures, leadership strategies, strategic planning initiatives, and collaboratively envisioning the future" [24] (p. 538). Therefore, universities should promote a pattern of development that is compatible with a safe environment, biodiversity, ecological balance, and intergenerational equity [25].

Previous studies $[23,25]$ have noted an increased consciousness about sustainability issues in society and their significant impact on campus activities, the environment, and communities. A way to look at the level of concern with sustainability is to focus on the news media because they are the central "interpretative system" of modern societies [26]. Moreover, according to Kiousis and McCombs [27], there is a causal relationship between the thematic priorities of the media and the relevance of social problems in the population [27]. As stated by Howland et al. [28] (p. 210), "studies show that the news media reflect and influence both public opinion and policy making". In particular, newspapers are considered to be the most important sources of information regarding the dissemination of new scientific knowledge [29]. Thus, determining the social concerns about sustainability expressed by the media has paramount importance for HEIs because media coverage is a key driver in shaping these concerns through "the placing of certain issues or problems foremost in the public mind" [30] (p. 2). Nevertheless, the media's communicative role is twofold: They voice the concerns of certain social groups related to fields such as sustainability that are interesting for HEIs, and they also reflect the efforts of HEIs' communication departments, who are trying to spread the work done by the HEIs in those fields.

In recent years, authors [30-34] have investigated a variety of newspaper articles in different countries concerning sustainability, sustainable development, and the environment. These countries have included the US, Mexico, Guatemala, France, the United Kingdom, Belgium, and South Africa. Overall, these articles have focused on identifying the reasons for the attention cycles of media coverage, which are aspects in the construction of the concepts and trends around sustainability. However, few studies have explored media attention to educational issues [35-37]. These articles have captured, summarized, synthesized, and commented on the role of social media to garner the interest of students and staff regarding environmental sustainability issues. Thus, Anderson [38] acknowledges that "there 
is a significant gap in our understanding of the framing of sustainable development discourse" [38] (p. 176), especially the connections among terms, sustainability, and education.

To help fill this gap, this research aims to improve the understanding of news coverage about sustainability and university because it reflects and influences the social perception of HEIs' sustainability efforts in Spain. This country was chosen because Spanish universities, through the Conference of Rectors of Spanish Universities (CRUE), show great interest in sustainability issues [20]. Moreover, the scientific production of green and sustainable science and technology papers is ranked fifth by output (4179 papers) in Spain, accounting for $5.3 \%$ of all world papers and exhibiting a mean yearly growth of $21.8 \%$ (3.3 points more than world growth), according to De Filippo et al. [39]. Spanish public perceptions on the role of universities regarding sustainability in society were collected through analysis of the print media. Considering this objective, the research questions are as follows:

RQ1: What are the main trends in the coverage of sustainability and university by Spanish newspapers in the MyNews database during the 2014-2017 period?

RQ2: How were sustainability and university topics reported and portrayed by Spanish newspapers to the public during the 2014-2017 period?

The study uses Spanish newspapers from the MyNews database of 1285 national press sources between 2014 and 2017, considering "sustainability" (because it is the most general term) and "university" (because, in Spain, this term is the most common way to refer to higher education) as the main keywords. We have used the probabilistic topic model called Latent Dirichlet Allocation (LDA) to analyze the large corpus and determine the themes with the highest frequency and greatest importance, as well as the relations between them [40]. The topic model methodology has already been applied in other sustainability studies using other sources of information. Székely and Brocke [41] applied topic modelling to obtain common topics and practices in sustainability reports published between 1999 and 2015 and emphasized that schools and education are key parts of any pertinent scheme aiming to improve overall sustainability through enhanced cooperation between governmental and social agents. Larran and Andrades [42], in their analysis of 15 academic journals that published articles on universities' social responsibility, identified social-economic development as a main topic of these articles.

The remainder of this paper is structured as follows. In Section 2, we describe the methodology applied and its suitability to our research questions. Then, key results and discussions are presented in Section 3, including the most relevant news sources and the main topics related to our aims. Finally, in the last section, we conclude with the most relevant features of our study.

\section{Materials and Methods}

This study develops a topic model, which is a text analysis method commonly applied in the social sciences, humanities, and beyond, based on news coverage. Thus, the topic model provides an automated procedure for coding the content of a very large corpus of text into a set of substantively meaningful coded groups called "topics" [43], uncovering topics and structures that a researcher using hand-coding methods might not otherwise detect. This method also allows researchers to discover patterns in much larger collections than it is possible to achieve by hand [44].

Text mining is a quantitative methodology that is useful for analyzing large amounts of related documents that, once considered together, build a corpus. Its aim is to generate inductively clusters of words through non-supervised (i.e., automatic) detection tools to obtain the underlying structure of the corpus [45]. Several text mining methods exist, and topic modelling is one of them [46]. Topic modelling techniques allow us to find hidden elements within a corpus constructed upon some basic elements called topics [47]. A topic is a reappearing pattern of words within a corpus, which has a probabilistic distribution over a determined vocabulary [40,44,46]. As a consequence, some words have certain probabilities of being semantically connected to other words within the corpus. Topic modelling treats each document within a corpus as a "bag of words" [43,48]. 
One of the most widely used probabilistic topic models is the so-called LDA [40,49]. The LDA model considers that documents "are represented as random mixtures over latent topics, where each topic is characterized by a distribution over words" [50] (p. 996). Then, each document "is generated by choosing a distribution over topics and then choosing each word in the document from a topic selected according to this distribution" [51] (p. 5528). LDA unveils the different proportions (or probabilities of occurrence) that topics have within the corpus. Consequently, with a compilation of documents as an input, a topic model can identify a set of interpretable "topics" or a set of words associated under a single theme. It also analyses these various word sets to determine word co-occurrence patterns across the corpus and then uses these results to define a map of the distribution of words into topics and topics into the sets $[43,44]$. This method allows us to systematically organize the collection of newspaper articles with specific parameters in order to identify hidden structures. It is also an increasingly useful tool for analyzing large, unstructured text collections [52].

The results obtained after the application of the LDA technique are subject to interpretation by the researcher based on her knowledge of the words (and the corresponding ideas) within a topic [53]. The researcher should link the results obtained with current knowledge of the issue [54] to advance her familiarity with it. That is, the results offer new knowledge that is scientifically connected to the researcher's previous knowledge. In sum, LDA offers a view of the hidden structure of a corpus. In Blei's words [49] (p. 79), "the inferred hidden structure resembles the thematic structure of the collection".

We used the open software R by R Core Team [55] in the RStudio interface developed by Team, Rs [56]. We worked with the topic models' package, which provides an interface to create code to fit an LDA model and a correlated topic model (CTM), in which correlation between topics is allowed with the variation expectation-maximization (VEM) algorithm implemented by Blei and co-authors; in other words, it allows for code to fit an LDA topic model with Gibbs sampling [57]. We also used the $t m$ R-package [58] to provide infrastructure for creating a corpus and transforming it into a document-term matrix, which is the input data necessary to run the package of topic models. Additionally, we improved the tm dictionary of the Spanish stop words list by removing stop words that caused noise in the analyses.

\section{The Data}

The corpus was created by gathering published news from 1285 Spanish newspapers and news agencies with local, national, and regional coverage between January 2014 and June 2017 (a total of 42 months).

Additionally, to our knowledge, Spanish newspaper coverage related to these topics has not been explored in recent years. The articles identified were fully digital and/or published by print media. The main parameters of the article search were the keywords "sustainability" and "university" in the Spanish database MyNews. The MyNews database was selected as an adequate source because of the number of local media outlets it contained; in fact, this database is one of the few databases including most Spanish newspapers and press agencies. It includes editorial data from 1996 onwards.

Articles were downloaded and screened manually as a first step to ensure that they fitted the inclusion criteria, considering the headlines of the news. The following table (see Table 1) numerically summarizes the results of the preparation process.

Regarding the number of topics, according to Kestel et al. [59], the number of latent topics must be defined in advance and allowed to be adjusted to the degree of specialization of the latent topics. To choose the appropriate number of topics to best fit our corpus, we applied the algorithm on ten, fifteen, eighteen, twenty, twenty-five, and thirty intervals and compared the results. 
Table 1. The corpus.

\begin{tabular}{cccccc}
\hline \multicolumn{7}{c}{ The Corpus } \\
\hline \multicolumn{7}{c}{ Years } \\
\hline Process & 2014 & 2015 & 2016 & 2017 & Total \\
Number of news stories downloaded: & 6948 & 12,440 & 12,665 & 9263 & 41,316 \\
Number of news stories screened manually: & 6088 & 3295 & 5081 & 2598 & 17,062 \\
Number of words screened manually: & $3,126,539$ & $1,706,036$ & $1,293,198$ & $2,432,196$ & $8,557,969$ \\
Number of words after removing stop-words: & $1,327,173$ & $1,676,781$ & 459,227 & $1,794,017$ & $5,257,198$ \\
\hline
\end{tabular}

Our final decision was to choose 20 as the number of topics, including 20 terms in each set of words. Some authors have advised selecting 20 topics when the corpus size is similar to ours (approximately five and a quarter million words) [40,44,60], but the optimal number of topics is a controversial issue [61]. Considering this matter, the results include a variety of topics, additionally based on the expertise of authors and the experience of authors such as $[44,62,63]$, who also applied topic modelling in their studies. Note that in the results, we capture the 9 most relevant topics among the 20 topics, so it will provide a better understanding of the themes across our corpus.

\section{Results and Discussion}

We used a topic model to approach our research questions by identifying clusters of words that ranked the probability of each word within a topic that describes the most frequently discussed patterns. From the primary list of the 1285 Spanish newspaper sources contained in the MyNews database, we obtained a representation of the 20 leading national newspaper sources, including online and print media. As a first finding, we introduce newspapers with the greatest coverage of universities and sustainability over the last four years. The second finding presents the main topics reported and portrayed in their coverage.

\subsection{The Agendas of Spanish Newspapers' Coverage of Sustainability and Universities}

In relation to our first research question, we introduce the most relevant newspaper sources in terms of the number of articles published over the years. According to Carvalho [64], broadsheet newspapers have the highest agenda setting impact among all types of media and thus will be expected to show the highest correlation with public agendas and social awareness. As a result of our first aim, we identify 446 news sources from the 1285 that published at least one article related to universities and sustainability. These sources include press and online media, considering that many newspapers currently publish the same content on their web sites as in the press media.

Regarding the news sources, 446 of 1285 print and online newspapers in the MyNews database had published at least one article related to these topics. Figure 1 illustrates the distribution of coverage of the 20 main news sources, of which the most relevant are Europa Press Agency, El Economista, Gente Digital, 20 Minutos, La Información, Econoticias, La Vanguardia, Ecodiario, ABC, El Dia, El Periodic, El País, La Verdad, Interempresas, La Voz de Galicia, Corresponsables, Teleprensa, Finanzas, and El Mundo e Ideal. Continuously, the highest news scores are attained by Europa Press, which is one of the leading news agencies in Spain, providing a large share of the news published by Spanish regional newspapers. It is important to emphasize that there are different patterns in the number of publications per year. Thus, Europa Press has had a steady issuance number. However, there was a slight decrease in the coverage by El Economista over the four years. In contrast, coverage of these topics by La Información and La Vanguardia have noticeably plummeted, especially over the last two years. Moreover, a similar trend was observed by El Dia. Hence, the coverage from the rest of the news sources remained stable. 


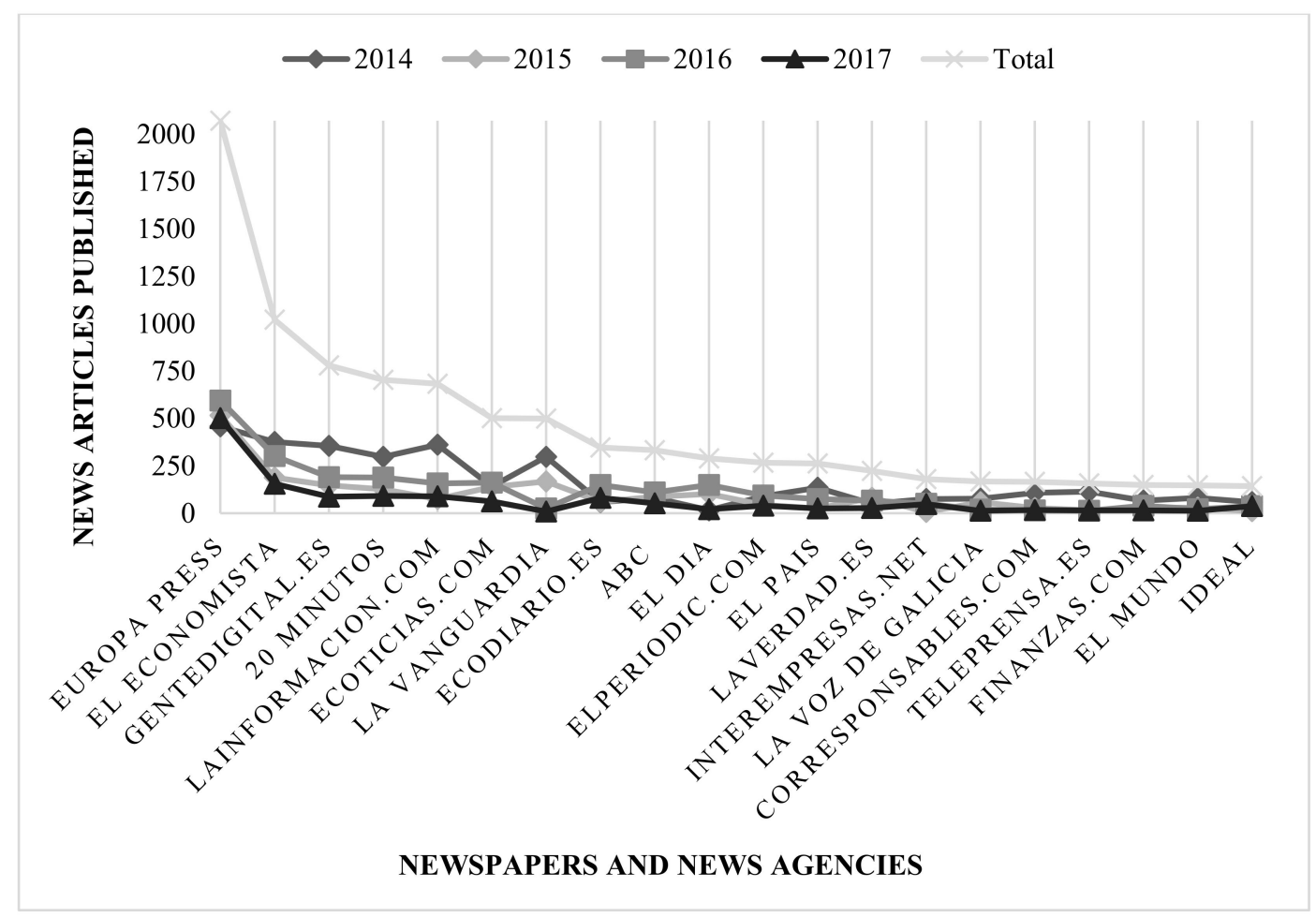

Figure 1. Leading Spanish news sources.

In a comparative analysis of the coverage of sustainability by 115 leading national newspapers based in forty-one countries in 2008 [31], the researchers identified the following Spanish newspapers: El Mundo, El País, ABC, El Correo, Diario Montañés, La Verdad, and Diario Vasco. These were considered the most important papers in Spain according to the criteria of circulation, area of circulation, and, if possible, private ownership. From these results, only three newspapers, El Mundo, El País, and ABC, have continued to have sustainability and universities prevalent in their agendas over the past six years, and they are not the newspapers with the most articles in our study.

The number of news items about sustainability and university declined slightly over time, with the most important general newspapers maintaining their number of news items. A possible explanation would be that when the university contributes something new and innovative in this field, it is included in news coverage, but later, as they become habitual activities, they lose relevance in their coverage by the media. For universities, this represents a challenge in their accountability and communication policies because of the great effort they make to integrate sustainability into their normal activities, which may not be correctly perceived by society.

\subsection{The Agendas of Spanish Newspapers Regarding Sustainability and Universities}

In relation to our second research question of how sustainability and university topics were reported and portrayed by Spanish newspapers to the public during the 2014-2017 period, we find that the main topics (in terms of a higher probability of occurrence within the published news) were dominated by nine sets of words. We call attention to the topic size of the overall corpus, indicating the weight of each set of keywords. We selected the most relevant topics (that is, the topics with the highest probability rankings that are present at least in $50 \%$ of the overall corpus). Moreover, the keywords displayed in Table 2 were identified as the greatest proportions inside of each set $(50 \%$ representation inside of their own topic). Considering the concepts related to those words, we have labelled the nine topics as follows: Sustainable development projects, University participation in public policies and regulations, Sustainable ideas for a responsible society, University leaders' commitment to environmental management, Higher education programs and research, University financial sustainability, Social responsibility and innovation, 
Energy-and water-efficient consumption systems, and Urban mobility and commuting modes. These topics are the basis for our analysis of the media coverage of sustainability and higher education issues in Spain during the 2014-2017 period because they illustrate the essence of media coverage of these issues.

Table 2. Main topics-newspaper coverage in 2014-2017.

\begin{tabular}{|c|c|c|c|c|c|}
\hline Rank & Label & $\mathbf{N}^{\circ}$ Topics & Topic Size & Percentage & Keywords \\
\hline 1 & $\begin{array}{c}\text { Sustainability } \\
\text { development projects }\end{array}$ & 6 & 0.07216164 & $7.22 \%$ & $\begin{array}{l}\text { Development, sustainability, } \\
\text { management, environment, } \\
\text { social, sector, objective. }\end{array}$ \\
\hline 2 & $\begin{array}{l}\text { University participation in } \\
\text { public policies and } \\
\text { regulations }\end{array}$ & 19 & 0.06435856 & $6.44 \%$ & $\begin{array}{l}\text { Law, article, administration, } \\
\text { people, agreement, } \\
\text { commission, right. }\end{array}$ \\
\hline 3 & $\begin{array}{l}\text { Sustainable ideas for a } \\
\text { responsible society }\end{array}$ & 4 & 0.06114246 & $6.11 \%$ & $\begin{array}{l}\text { Society, social, sustainability, } \\
\text { to do, model, economy, future, } \\
\text { system. }\end{array}$ \\
\hline 4 & $\begin{array}{l}\text { University leaders' } \\
\text { commitment to } \\
\text { environmental } \\
\text { management }\end{array}$ & 1 & 0.05882649 & $5.88 \%$ & $\begin{array}{l}\text { University, director, president, } \\
\text { sustainability, environment, } \\
\text { Andalucía. }\end{array}$ \\
\hline 5 & $\begin{array}{l}\text { Higher education } \\
\text { programs and research }\end{array}$ & 8 & 0.05518858 & $5.52 \%$ & $\begin{array}{l}\text { University, research, training, } \\
\text { students, education, pupils *. }\end{array}$ \\
\hline 6 & $\begin{array}{l}\text { University financial } \\
\text { sustainability }\end{array}$ & 9 & 0.05467380 & $5.47 \%$ & $\begin{array}{l}\text { Euro, government, plan, } \\
\text { board, university, finance. }\end{array}$ \\
\hline 7 & $\begin{array}{l}\text { Social responsibility and } \\
\text { innovation }\end{array}$ & 16 & 0.05050338 & $5.05 \%$ & $\begin{array}{l}\text { Sustainability, social, } \\
\text { innovation, Málaga, company, } \\
\text { sector, smart, forum. }\end{array}$ \\
\hline 8 & $\begin{array}{c}\text { Energy- and } \\
\text { water-efficient } \\
\text { consumption systems }\end{array}$ & 17 & 0.05019023 & $5.02 \%$ & $\begin{array}{l}\text { Energy, water, consumption, } \\
\text { efficiency, system, systems. }\end{array}$ \\
\hline 9 & $\begin{array}{l}\text { Urban mobility and } \\
\text { commuting modes }\end{array}$ & 18 & 0.04955120 & $4.96 \%$ & $\begin{array}{l}\text { Company, mobility, group, } \\
\text { transport, commercial, social. }\end{array}$ \\
\hline
\end{tabular}

* pupils: The original word in Spanish is synonymous with "students".

Ranked from a higher to a lower probability of occurrence within the corpus, the first topic is Sustainable development projects ("development", "sustainability", "management", "environment", "social", "sector", and "objective" are the most frequent words within this topic). This topic mirrors the social perception of universities as agents that implement sustainability-related projects, actively participating in supporting the sustainable management of ecosystem preservation. More precisely, the topic covers HEIs' specific activities (connected with a university's outreach and its innovation commitment) in this field more than generic coverage of sustainability values. Moreover, one of the main missions perceived by universities is to be able to respond to demands regarding sustainable development to create a better world.

In this context, the second topic, University participation in public policies and regulations (gathering the words "law", "article", "administration", "people", "agreement", "commission", and "right"), is related to expert professors who can improve sustainability public policies by advising lawyers and policymakers. In other words, this topic covers the transfer of knowledge concerning sustainability from university academics to society as a whole through their specialized understanding of the issue. The topic is related to the so-called "HEIs' third mission, the "generation, use, application, and exploitation of knowledge and other university capabilities outside academic environments: business, public sector organizations, and the wider community" [65] (p. 2). This topic points towards the achievement of social impact and fostering partnerships with governments and communities [66]. Universities also have a potential influence on the industry and on government regulations to attain a more sustainable future. HEIs work together with policy makers and other stakeholders to identify 
policy priorities and problems, assess better options to implement solutions, and finally evaluate policies [66].

HEIs are well-situated agents to foster cooperative links between governments and other social constituencies. Székely and Brocke [41] emphasized that schools and education are key components of any pertinent scheme that aims to improve overall sustainability through enhanced cooperation between governmental and social agents.

The third topic, Sustainable ideas for a responsible society (mainly composed of the words "society", "social", "sustainability", "to do", "model", "economy", "future", and "system"), emphasizes universities" contribution to the discussion about sustainability within different social and economic models. This is a key debate on the values and ideas needed for a sustainable future. In this regard, universities in general have assumed the main values of sustainability within a large set of United Nations declarations and established academic networks with the aim of fostering conversation about the Earth's future. They offer a trusted set of scientific concepts for the debate on more sustainable socio-economic systems.

Furthermore, the fourth topic, University leaders' commitment to environmental management (including the keywords "university", "director", "president", "sustainability", "environment", and "Andalucía"), points towards university leadership's commitment to "greening the campus" policies (with high media coverage in the case of Andalusian universities). This concern clearly exemplifies the idea of university campuses as advanced social labs. HEIs' impulse for social-economic development involves different activities that generate economic impacts in their communities, with a particularly clear impact on the regional environment. In addition, universities contribute to the green economic development of their immediate geographical milieus by working with local governments and businesses in the concentration of high-tech activities on their campuses [67].

In the fifth topic, Sustainable education and research ("university", "research", "training", "students", "education", and "pupils"), society perceives the relationship between sustainability and the basic university functions of teaching and research. From a university's perspective, this relationship implies integrating sustainable concepts into its traditional mission. Furthermore, universities play an important role by becoming places for the interchange of new ideas through teaching and research, which can promote and disseminate more advanced sustainability activities and be vehicles for social change [68]. This topic also points to the move towards curriculum adaptation including general perspectives about sustainability development in different subjects. At the same time, the research agenda on environmental, social, and economic sustainability attains greater relevance for all academic areas.

The sixth topic, University financial sustainability (keywords "euro" (the currency), "government", "plan", "board", "university", and "finance"), could reflect social concerns about the long-term economic viability of the university itself. The consequences of the 2008 Great Recession involved multiple challenges for universities, chiefly in terms of fund depletion and shifts in sources of finance for European universities. As an illustration of the European context in relation to Portuguese universities, Aleixo et al. [6] concluded with the recommendation that the government should increase financial support for HEIs. They identified the lack of financial resources as the main barrier to the sustainable development of HEIs. In addition, the economic crisis in Portugal has had an enormous negative impact on HEI funding. This result has been pervasive in different studies related to other European higher education systems, and it is also found in this research. Indeed, within the ideas on the university-sustainability relationship disseminated by the Spanish media included in the MyNews database, finance was seen to be a prominent concern. As a sample of this issue, in 2015, an article in El Mundo newspaper reported the university's Social Council request to the board of the University of Valladolid for a tighter budget policy: "As a consequence of the crisis in the new fiscal years of the University of Valladolid, it should exercise prudence in the quantification and management of the budget and look for additional and alternative sources of funding." (Original version: ... "como consecuencia de la crisis, en los próximos ejercicios la Universidad de Valladolid «deberá extremar la 
prudencia en la cuantificación y gestión del presupuesto y buscar fuentes de financiación adicionales y alternativas»" El Mundo newspaper, 11 April 2015).

The seventh topic in our model, Social responsibility and innovation, (keywords "sustainability", "social", "innovation", "Málaga", "company", "sector", "smart", and "forum"), refers to another aspect of the "third mission" of the university: its contribution to economic and social innovation. It connects social innovation (developed by HEIs and other organizations), sustainability, and improvement in people's well-being, aiming for higher economic, technological, and environmental development [69]. Within this behavior are several activities involving knowledge production or solution creation and demonstrations of implementation in economic or social fields. These news articles show some of the efforts of universities, in collaboration with companies, to seek and apply new technological solutions to the main environmental, social, and economic challenges of current society.

The last two topics among the top nine topics in our model are Energy- and water-efficient consumption systems (keywords "energy", "water", "consumption", "efficiency", "system", and "systems") and Urban mobility and commuting modes (Keywords "company", "mobility", "group", "transport", "commercial", and "social"). These topics are related to some of the main environmental problems of society: energy, water, and mobility. Universities are active in these areas in two ways: their activities in research and the transfer of knowledge in these specific areas and the implementation of internal actions to apply sustainable practices to their own activities. Here, we find worries about greener campuses generalized among HEIs worldwide, as shown by specific university rankings such as the UI GreenMetric ranking (https://greenmetric.ui.ac.id), which refers to universities' sustainable performance and indicators in education, infrastructure, energy and climate change, waste management, water consumption, and transport and further developments based on it [70]. Furthermore, the "Commitment to sustainable practices of HEIs on the occasion of the Río+20 conference" states that signatories universities agreed to consider the following: "(i) reducing the environmental footprint through energy, water, and material resource efficiencies in our buildings and facilities; (ii) adopting sustainable procurement practices in our supply chains and catering services; (iii) providing sustainable mobility options for students and faculty; (iv) adopting effective programs for waste minimization, recycling, and reuse, and (v) encouraging more sustainable lifestyles." [71] (p. 1). Since this 2012 Rio+20 declaration, great improvements have been achieved by HEIs, but universities should reinforce their environmental policies (specifically those related to energy, water use, and waste treatment) [7].

Summarizing the results for our nine topics, it appears that the social perception of universities and sustainability (as reflected in the news) are focused on four main aspects of universities' activities. First, Topics 1,2, and 3 focus on the contribution to society through the transfer of expert knowledge. This contribution channels ideas for the debate on sustainability and adequate socio-economic models; it also offers advice to legislators and policymakers for proper regulation and the implementation of specific projects in this area. Second, in Topics 5 and 7, the inclusion of sustainability and sustainable development ideas in the university's operations was derived from the three missions of universities (teaching, research, and knowledge transfer to society). Third, in Topics 4, 8, and 9, the university's commitment to solving the environmental problems of society (including the specific university's environmental difficulties) serves as an example. Lastly, Topic 6 is related to the economic sustainability of the university itself in an era of financial and economic troubles for society as a whole.

If we relate these topics to the perspective of the universities themselves, collected in the Lozano model [23], which includes internal stakeholders' attitudes and behaviors in three fundamental aspects: (1) university governance (leadership, engagement, institutional framework, and policies); (2) community outreach (campus operations, research, curriculum, and competencies); and (3) sustainability assessment and reporting, we observe that almost all the issues considered by the media are related to the first two parts of the model, that is, the leadership of the university management to promote sustainability and the typical activities of the university towards society (that is, community outreach). Universities could make an effort in assessment and reporting that is not picked up by 
published opinions to show their activities and commitment in the field of sustainability to a greater extent. University management may be interested in analyzing whether the perception illustrated by the newspapers coincides with the objectives of the institution and the importance of evaluation and communication in order to arouse greater interest in its activities in society (given the slightly decreasing evolution in the number of news items and their reduced presence in the main media).

\section{Conclusions}

In order to achieve social legitimacy, the stakeholder approach stresses the importance of considering the interests of external stakeholders in university activities. This article shows a method, using a topic model, for university managers to better understand the social perception of university sustainability through the analysis of the news collected in the written media.

The paper identifies the twenty most relevant newspapers based on the number of articles that cover sustainability and university issues. Among them, the six newspapers with the highest number of published articles are Europa Press, El Economista, Gente Digital, 20 Minutos, La Información, and Econoticias. Only two of these newspapers specialize in sustainability topics; nevertheless, they do not cover sustainability and university issues more frequently than the others.

We have found nine main topics about university sustainability from the news. In addition, the order of the topics (taking into account the weight of each topic within the corpus; see Table 1) that have attracted more or less public attention allows HEIs to reconsider their activities on the sustainability field.

The nine topics mirror the most relevant ideas reported in Spanish newspaper agendas. The results are aligned with the importance of HEIs as drivers of sustainability through universities' main activities, teaching, research, outreach, and campus operations, as well as their potential influence in the local, regional, national, and international community. As a consequence, universities could have a better understanding and a greater awareness of the public interest in their sustainability actions through the social perceptions gathered regarding the nine topics. The university's positions on the environment and sustainability might potentiate social change by "embracing the language and the ensemble of values, beliefs, practices, policies, and laws" [72]. In summary, the nine most relevant topics in our model describe the main features of how the public perceives (or is encouraged to perceive) what sustainability means in the context of HEIs. Our results shed light on several aspects of this interconnection from the social perception perspective. Therefore, we find some relationships among sustainable development, HEIs' missions and behaviors, governmental policies, university funding, social and economic innovation, and green campuses within the overall goal of sustainability.

The ordering of the topics obtained, and their relative weighing within the corpus, sheds new light on the priorities for universities' behavior. On the one side, taking the three topics with a participation in the corpus above the $6 \%$ threshold, they invite the university's involvement in sustainability efforts with a wide social usefulness (development projects, public policies and regulations, and the offering of ideas). Considering this information, universities' authorities should encourage the development of innovative projects in the field of sustainability and inform public opinion about them. In the same way, they will be aware of the importance of the participation of their faculty in the debates on regulations and public policies and, therefore, promote it with incentives. On the other side, the last two topics (related to efficient energy and water consumption and mobility) are related to much more specific applications of the general sustainability ideas.

As universities are considered "vehicles for social change", they must be an example in the development of all their activities in this direction. Education, research, and knowledge diffusion based on scientific grounds (that is, greater engagement with society as a whole) all establish a solid framework for universities to develop actions together with social actors that have a deep impact on long-term sustainability. The social debate on sustainability includes, together with environmental issues, social challenges and economic aspects. The adoption of a crucial agenda of sustainable development goals boosts new legislation and changes the priorities of policy makers. Universities, as 
the topics in this study reflect, use their expert knowledge to collaborate with society as a whole to tackle these sustainability challenges. To become an important social actor with regard to sustainability, universities must recognize the inclusiveness, active participation, and interactions of all interested parties. They can do so by taking into account the stakeholder voices for university governance in order to maximize their contribution to society.

This study shows that the analysis of the social perception of sustainability and universities could improve the capacity of professionals, scientists, and legislators to better understand the corresponding problems and needs at different levels. Hence, relevant issues and the general opinions of all actors could also be included as part of the self-evaluation of the performance of universities in a continuous process to innovate the management system. This article contributes to providing an image of the social perceptions of the activity of universities in the field of sustainability. This image can allow those responsible for HEIs to make decisions based, not only on their own perceptions, but also on the valuations of society as a whole, in order to overcome the topical perception of the university as an ivory tower isolated from the real problems of society.

Our study has an exploratory aim focused on the identification of the main topics covered by Spanish newspapers in the 2014-17 period. Those topics represent wide themes and trends. So, new research is needed to delve within the universities' specific activities related to sustainability. It should be noted also that universities could respond differently to the same stimuli because they have diverse structural and organizational characteristics.

Future work should also consider other media sources and analyze the evolution of these topics over the years to note the impact on them of significant events or summits related to sustainability and/or universities.

Author Contributions: C.E.B.A. led the structure of the study and the process of collecting, organizing, and analyzing the data from MyNews and an overall discussion of the results. J.R.-P. and C.E.B.A. developed the methods and materials to approach the research questions and wrote the respective methods and the discussion. L.A.S.H. developed the literature review and contributed to the collection and organization of the data. F.C. contributed to the analysis, interpretation, and discussion of the results. All the authors contributed to writing and revising the article and the approval of the manuscript. All authors have read and agreed to the published version of the manuscript.

Funding: This research was funded by the Madrid Regional Government and the European Social Fund, Project "Towards the Consolidation of Inclusive Cities: A Challenge for Madrid" (H2019/HUM-5744).

Acknowledgments: The authors would like to thank Bettina Grün (Johanes Kepler Universität Linz, Austria) and Sandra Caeiro (Universidade Aberta, Portugal) for their advice, and the three anonymous reviewers for their insightful analysis of the manuscript.

Conflicts of Interest: The authors declare no conflict of interest.

\section{References}

1. WCED. Our Common Future; Oxford University Press: Oxford, UK, 1987.

2. Daub, C.H. Assessing the quality of sustainability reporting: An alternative methodological approach. J. Clean. Prod. 2007, 15, 75-85. [CrossRef]

3. Aktas, C.B.; Whelan, R.; Stoffer, H.; Todd, E.; Kern, C.L. Developing a university-wide course on sustainability: A critical evaluation of planning and implementation. J. Clean. Prod. 2015, 106, 216-221. [CrossRef]

4. Lozano, R. The state of sustainability reporting in universities. Int. J. Sustain. High. Educ. 2011, 12, 67-78. [CrossRef]

5. Wright, T.; Horst, N. Exploring the ambiguity: What faculty leaders really think of sustainability in higher education. Int. J. Sustain. High. Educ. 2013, 14, 209-227. [CrossRef]

6. Aleixo, A.M.; Leal, S.; Azeiteiro, U.M. Conceptualization of sustainable higher education institutions, roles, barriers, and challenges for sustainability: An exploratory study in Portugal. J. Clean. Prod. 2018, 172, 1664-1673. [CrossRef]

7. Beynaghi, A.; Moztarzadeh, F.; Maknoon, R.; Waas, T.; Mozafari, M.; Hugé, J.; Leal Filho, W. Towards an orientation of higher education in the post Rio +20 process: How is the game changing. Futures 2014, 63, 49-67. [CrossRef] 
8. Filho, W.L.; Raath, S.; Lazzarini, B.; Vargas, V.R.; de Souza, L.; Anholon, R.; Quelhas, O.L.G.; Haddad, R.; Klavins, M.; Orlovic, V.L. The role of transformation in learning and education for sustainability. J. Clean. Prod. 2018, 199, 286-295. [CrossRef]

9. Vaughter, P.; McKenzie, M.; Lidstone, L.; Wright, T. Campus sustainability governance in Canada. A content analysis of post-secondary institutions' sustainability policies. Int. J. Sustain. High. Educ. 2016, 17, 16-39. [CrossRef]

10. Velazquez, L.; Munguia, N.; Platt, A.; Taddei, J. Sustainable university: What can be the matter? J. Clean. Prod. 2006, 14, 810-819. [CrossRef]

11. Findler, F.; Schoenherr, N.; Lozano, R.; Reider, D.; Martinuzzi, A. The impacts of higher education institutions on sustainable development A review and conceptualization. Int. J. Sustain. High. Educ. 2019, 20, 23-38. [CrossRef]

12. Calder, W.; Clugston, R.M. International efforts to promote higher education for sustainable development. Plan. High. Educ. 2003, 31, 30-44.

13. Grindsted, T. Sustainable universities - From declarations on sustainability in higher education to national law. Environ. Econ. 2011, 2, 29-36. [CrossRef]

14. Lozano, R.; Lukman, R.; Lozano, F.J.; Huisingh, D.; Lambrechts, W. Declarations for sustainability in higher education: Becoming better leaders, through addressing the university system. J. Clean. Prod. 2013, 48, 10-19. [CrossRef]

15. Sayed, A.; Asmuss, M. Benchmarking tools for assessing and tracking sustainability in higher educational institutions. Int. J. Sustain. High. Educ. 2013, 14, 449-465. [CrossRef]

16. Ceulemans, K.; Molderez, I.; Van Liedekerke, L. Sustainability reporting in higher education: A comprehensive review of the recent literature and paths for further research. J. Clean. Prod. 2015, 106, 127-143. [CrossRef]

17. Alghamdi, N.; den Heijer, A.; de Jonge, H. Assessment tools' indicators for sustainability in universities: An analytical overview. Int. J. Sustain. High. Educ. 2017, 18, 84-115. [CrossRef]

18. Parvez, N.; Agrawal, A. Assessment of sustainable development in technical higher education institutes of India. J. Clean. Prod. 2019, 214, 975-994. [CrossRef]

19. Findler, F.; Schönherr, N.; Lozano, R.; Stacherl, B. Assessing the impacts of higher education institutions on sustainable development-An analysis of tools and indicators. Sustainability 2019, 11, 59. [CrossRef]

20. Caeiro, S.; Sandoval Hamón, L.A.; Martins, R.; Bayas Aldaz, C.E. Sustainability assessment and benchmarking in higher education institutions-A critical reflection. Sustainability 2020, 12, 543. [CrossRef]

21. Herremans, I.M.; Nazari, J.A.; Mahmoudian, F. Stakeholder relationships, engagement, and sustainability reporting. J. Bus. Ethics 2016, 138, 417-435. [CrossRef]

22. Freeman, R.E. Strategic Management: A Stakeholder Approach; Pitman Publishers: Boston, MA, USA, 1984.

23. Lozano, R. A tool for a graphical assessment of sustainability in universities (GASU). J. Clean. Prod. 2006, 14, 963-972. [CrossRef]

24. Moore, J. Barriers and pathways to creating sustainability education programs: Policy, rhetoric and reality. Environ. Educ. Res. 2005, 11, 537-555. [CrossRef]

25. Alshuwaikhat, H.M.; Abubakar, I. An integrated approach to achieving campus sustainability: Assessment of the current campus environmental management practices. J. Clean. Prod. 2008, 16, 1777-1785. [CrossRef]

26. Schmidt, A.; Ivanova, A.; Schaefer, M.S. Media attention for climate change around the world: A comparative analysis of newspaper coverage in 27 countries. Glob. Environ. Chang. 2013, 23, 1233-1248. [CrossRef]

27. Kiousis, S.; McCombs, M. Agenda-setting effects and attitude strength: Political figures during the 1996 presidential election. Commun. Res. 2004, 31, 36-57. [CrossRef]

28. Howland, D.; Becker, M.L.; Prelli, L.J. Merging content analysis and the policy sciences: A system to discern policy-specific trends from news media reports. Policy Sci. 2006, 39, 205-231. [CrossRef]

29. Nelkin, D.; Elias, J. Selling science: How the press covers science and technology. J. Public Health Policy 1996, 17, 501-503. [CrossRef]

30. Holt, D.; Barkemeyer, R. Media coverage of sustainable development issues-Attention cycles or punctuated equilibrium? Sustain. Dev. 2012, 20, 1-17. [CrossRef]

31. Barkemeyer, R.; Figge, F.; Holt, D. Sustainability-related media coverage and socioeconomic development: A regional and north-south perspective. Environ. Plan. C Politics Space 2013, 31, 716-740. [CrossRef] 
32. Guo, X.; Marinova, D. Environmental awareness in China: Facilitating the greening of the economy. In Proceedings of the 19th International Congress on Modelling and Simulation, Perth, Australia, 12-16 December 2011.

33. Lewis, T.L. Media representations of "sustainable development" sustaining the status quo? Sci. Commun. 2000, 21, 244-273. [CrossRef]

34. Orna-Montesinos, C. The discourses of sustainability in news magazines: The rhetorical construction of journalistic stance. Rev. Esp. Lingüíst. Apl. J. Appl. Linguist. 2015, 28, 442-464. [CrossRef]

35. Carpenter, S.; Takahashi, B.; Cunningham, C.; Lertpratchya, A.P. The Roles of Social Media in Promoting Sustainability in Higher Education. Int. J. Commun. 2016, 10, 4863-4881.

36. De Siqueira, A.B.; Berardi, A.; Mistry, J.; Rothberg, D. Experimenting with media education, civic engagement, and sustainability. In Communication and Information Technologies Annual: Digital Empowerment: Opportunities and Challenges of Inclusion in Latin America and the Caribbean; Robinson, L., Schulz, J., Dunn, H.S., Eds.; Emerald Group Publishing Ltd: Bingley, UK, 2017; Volume 12, pp. 41-61.

37. Hamid, S.; Ijab, M.T.; Sulaiman, H.; Anwar, R.M.; Norman, A.A. Social media for environmental sustainability awareness in higher education. Int. J. Sustain. High. Educ. 2017, 18, 474-491. [CrossRef]

38. Anderson, A. Media, politics and climate change: Towards a new research agenda. Sociol. Compass 2009, 3, 166-182. [CrossRef]

39. De Filippo, D.; Sandoval-Hamón, L.A.; Casani, F.; Sanz-Casado, E. Spanish universities' sustainability performance and sustainability-related R \& D+ I. Sustainability 2019, 11, 5570. [CrossRef]

40. Blei, D.M. Probabilistic topic models. Commun. ACM 2012, 55, 77-84. [CrossRef]

41. Székely, N.; Brocke, V.J. What can we learn from corporate sustainability reporting? Deriving propositions for research and practice from over 9500 corporate sustainability reports published between 1999 and 2015 using topic modelling technique. PLoS ONE 2017, 12, 1-27. [CrossRef]

42. Larran-Jorge, M.; Andrades-Pena, F.J. Analysing the literature on university social responsibility: A review of selected higher education journals. High. Educ. Q. 2017, 71, 302-319. [CrossRef]

43. Mohr, J.W.; Bogdanov, P. Introduction-Topic models: What they are and why they matter. Poetics 2013, 41, 545-569. [CrossRef]

44. DiMaggio, P.; Nag, M.; Blei, D. Exploiting affinities between topic modeling and the sociological perspective on culture: Application to newspaper coverage of U.S. government arts funding. Res. Output Contrib. J. 2013, 41, 570-606. [CrossRef]

45. Bauer, M.W.; Bicquelet, A.; Suerdem, A.K. Text Analysis: An Introductory Manifesto; SAGE Benchmarks in Social Research Methods; SAGE Publications Ltd: London, UK, 2014.

46. Brett, M.R. Topic modeling: A basic introduction. J. Digit. Humanit. 2012, 2, 1-5.

47. Hannigan, T.R.; Haans, R.F.J.; Vakili, K.; Tchalian, H.; Glaser, V.L.; Wang, M.S.; Kaplan, S.; Jennings, P.D. Topic modeling in management research: Rendering new theory from textual data. Acad. Manag. Ann. 2019, 13, 586-632. [CrossRef]

48. Meeks, E.; Weingart, S.B. The digital humanities contribution to topic modeling. J. Digit. Humanit. 2012, 2, 1-6.

49. Blei, D.M. Topic modeling and digital humanities. J. Digit. Humanit. 2012, 2, 1-5.

50. Blei, D.M.; Ng, A.Y.; Jordan, M.I. Latent dirichlet allocation. J. Mach. Learn. Res. 2003, 3, 993-1022. [CrossRef]

51. Griffiths, T.L.; Steyvers, M. Finding scientific topics. Proc. Natl. Acad. Sci. USA 2004, 101, 5228-5235. [CrossRef]

52. Wallach, H.M.; Murray, I.; Salakhutdinov, R.; Mimno, D. Evaluation methods for topic models. In Proceedings of the 26th Annual International Conference on Machine Learning, ACM, New York, NY, USA, 14-18 June 2009; pp. 1105-1112. Available online: http://dirichlet.net/pdf/wallach09evaluation.pdf (accessed on 14 June 2009).

53. Chang, J.; Boyd-Graber, J.L.; Wang, C.; Gerrish, S.; Blei, D.M. Reading tea leaves: How humans interpret topic models. Neural Inf. Process. Syst. 2009, 31, 1-9.

54. Ramage, D.; Rosen, E.; Chuang, J.; Manning, C.D.; McFarland, D.A. Topic Modeling for the Social Sciences. In Proceedings of the NIPS 2009 Workshop on Applications for Topic Models, Whistler, BC, Canada, 11 December 2009; p. 11. Available online: http://vis.stanford.edu/files/2009-TopicModels-NIPS-Workshop. pdf (accessed on 11 December 2009). 
55. R Core Team. R: A Language and Environment for Statistical, $R$ Foundation for Statistical Computing; The R Foundation: Vienna, Austria, 2017; Available online: http://softlibre.unizar.es/manuales/aplicaciones/r/ fullrefman.pdf (accessed on 10 January 2014).

56. Rs. Team. RStudio: Integrated development for R; RStudio Inc.: Boston, MA, USA, 2015; Available online: https://rstudio.com/ (accessed on 10 January 2014).

57. Hornik, K.; Grün, B. Topicmodels: An R package for fitting topic models. J. Stat. Softw. 2011, 40, 1-30. [CrossRef]

58. Meyer, D.; Hornik, K.; Feinerer, I. Text mining infrastructure in R. J. Stat. Softw. 2008, 25, 1-54. [CrossRef]

59. Krestel, R.; Fankhauser, P.; Nejdl, W. Latent dirichlet allocation for tag recommendation. In Proceedings of the third ACM Conference on Recommender Systems, ACM, New York, NY, USA, 23 October 2009; pp. 61-68.

60. Savoy, J. Authorship attribution based on a probabilistic topic model. Inf. Process. Manag. 2013, 49, 341-354. [CrossRef]

61. Dagiliute, R.; Liobikiene, G. University contributions to environmental sustainability: Challenges and opportunities from the Lithuanian case. J. Clean. Prod. 2015, 108, 891-899. [CrossRef]

62. Jaworska, S.; Nanda, A. Doing well by talking good: A topic modelling-assisted discourse study of corporate social responsibility. Appl. Linguist. 2018, 39, 373-399. [CrossRef]

63. Rodriguez-Pomeda, J.; Casani, F. Legitimating the world-class university concept through the discourse of elite universities' presidents. High. Educ. Res. Dev. 2016, 35, 1269-1283. [CrossRef]

64. Carvalho, A. Representing the politics of the greenhouse effect: Discursive strategies in the British media. Crit. Discourse Stud. 2005, 2, 1-29. [CrossRef]

65. Molas-Gallart, J.; Salter, A.; Patel, P.; Scott, A.; Duran, X. Measuring Third Stream Activities. Final Report to the Russell Group of Universities; SPRU, University of Sussex: Brighton, UK, 2002; pp. 1-85.

66. El-Jardali, F.; Ataya, N.; Fadlallah, R. Changing roles of universities in the era of SDGs: Rising up to the global challenge through institutionalising partnerships with governments and communities. Health Res. Policy Syst. 2018, 16, 33-38. [CrossRef] [PubMed]

67. Trencher, G.; Nagao, M.; Chen, C.; Ichiki, K.; Sadayoshi, T.; Kinai, M.; Kamitani, M.; Nakamura, S.; Yamauchi, A.; Yarime, M. Implementing sustainability co-creation between universities and society: A typology-based understanding. Sustainability 2017, 9, 594. [CrossRef]

68. Sandoval Hamón, L.A.; Bayas Aldaz, C.B.; Rodríguez Pomeda, J.; Sánchez Fernández, F.; Casani Fernández de Navarrete, F. From ecocity to ecocampus: Sustainability policies in university campuses. Int. J. Sustain. Dev. Plan. 2016, 12, 541-551. [CrossRef]

69. Jali, M.N.; Abas, Z.; Ariffin, A.S. Corporate social responsibility and corporate social innovation: A Conceptual understanding. In Proceedings of the 17th Annual Conference of the Asian Academic Accounting Association, Kuching, Sarawak, Malaysia, 20-22 November 2016; SHS Web of Conferences: Kuching, Sarawak, Malaysia, 2017.

70. Suwartha, N.; Sari, R.F. Evaluating UI GreenMetric as a tool to support green universities development: Assessment of the year 2011 ranking. J. Clean. Prod. 2013, 61, 46-53. [CrossRef]

71. Rio+20 United Nations Conference on Sustainable Development Commitment to Sustainable Practices of Higher Education Institutions. Available online: https://sustainabledevelopment.un.org/content/documents/ 1889HEI\%20Declaration\%20English\%20new\%20version.pdf (accessed on 15 December 2019).

72. Livesey, S.M.; Hartman, C.L.; Stafford, E.R.; Shearer, M. Performing sustainable development through eco-collaboration: The ricelands habitat partnership. J. Bus. Commun. 2009, 46, 423-454. [CrossRef]

(C) 2020 by the authors. Licensee MDPI, Basel, Switzerland. This article is an open access article distributed under the terms and conditions of the Creative Commons Attribution (CC BY) license (http://creativecommons.org/licenses/by/4.0/). 